\section{Detection of point mutations at codon 12 of KI-ras in ophthalmic pterygia}

\begin{abstract}
Aims Ophthalmic pterygium is a potentially vision-threatening lesion of unknown etiology, related to an exposure to solar light. Mutations to the ras genes are frequently observed in lesions related to an exposure to solar light. The present study aims at screening pterygia for mutations at codons $\mathbf{1 2}$ and 13 of the ras genes.
\end{abstract}

Methods In all, 50 pterygia were examined, together with respective blood samples and specimens of normal conjunctiva. A PCR reaction was performed to amplify sequences containing codons 12 and 13 of Ki-ras, H-ras, and N-ras. An RFLP analysis was then performed to detect point mutations at codon 12. The mutational status at codons $\mathbf{1 2}$ and $\mathbf{1 3}$ was further explored with sequencing of PCR products.

Results RFLP analysis revealed Ki-ras

${ }^{1}$ Department of Clinical Virology

University of Crete, Greece

${ }^{2}$ Department of Ophthalmology

University of Crete, Greece

Correspondence:

ET Detorakis

University Hospital of

Alexandroupolis

68100 Dragana

Alexandroupolis Thrace

Greece

Tel: +302551083492

Fax: + 302810221711

E-mail: detorakis@

hotmail.com; detorakis@

jsei.ucla.edu

Received: 5 September 2003

Accepted: 12 January 2004

Published online: 2 July

2004 mutations at codon 12 in five (10\%) of pterygia, whereas $\mathrm{H}$-ras or $\mathrm{N}$-ras mutations were not observed. Sequencing confirmed Ki-ras mutations at codon 12 and revealed absence of mutations at codon 13. The presence of Ki-ras mutations was significantly correlated with postoperative recurrence $(P=0.02)$ and young age $(P=0.04)$. Mutations were not observed in specimens of blood or normal conjunctiva for any of the genes examined.

Conclusions The absence of N-ras mutations is in agreement with previous reports concerning mucosal lesions. The detection of Ki-ras mutations and the association with postoperative recurrence implies a possible role of Ki-ras in the clinical profile of pterygium. The mechanism of Ki-ras mutations is unclear and could be independent of the action of UV light. Eye (2005) 19, 210-214. doi:10.1038/sj.eye.6701452 Published online 2 July 2004

Keywords: pterygium ras gene mutation
ET Detorakis ${ }^{1,2}$, A Zafiropoulos², DA Arvanitis ${ }^{1}$ and DA Spandidos ${ }^{1}$

\section{Introduction}

Ophthalmic pterygium is a lesion of the corneoscleral limbus that, apart from local inflammation and disfigurement, can also expand towards the central cornea and threaten vision. ${ }^{1}$ Although the pathogenesis remains obscure, the importance of heredity, possibly in an autosomal dominant form, as well as environmental factors, such as microtrauma by dust particles or exposure to solar radiation, especially scattered light (albedo), has long been recognised. ${ }^{2}$ The ultraviolet radiation (UVR), especially UVR-A and UVR-B (290-400 nm), is considered the most dangerous. ${ }^{3}$ There is growing evidence that pterygium is a proliferative, rather than degenerative, condition. ${ }^{4}$ Experimental findings, such as detection of loss of heterozygosity $(\mathrm{LOH})_{1}^{4,5}$ association with oncogenic viruses, ${ }^{6}$ and mutations in $\mathrm{p} 53,{ }^{7}$ as well as clinical evidence, such as progressive growth and frequent postoperative recurrences, ${ }^{1,5}$ support the concept that pterygium may be considered a benign neoplastic condition. Based on immunohistochemistry with monoclonal antibodies against p53 and vimentin, it has been proposed that pterygia may arise from a vimentin-expressing, altered limbal epithelial basal cell, the so-called 'pterygium cell' 8

However, the exact molecular events leading to pterygium development are not clear. The frequent detection of $\mathrm{LOH}$, which may result from exposure to UVR, ${ }^{4}$ supports the involvement of tumour suppressor genes (TSGs) in the pathogenesis of pterygium. ${ }^{5}$ Proto-oncogene sequences may also be affected by UVR. ${ }^{9,10}$ Mutations in genes of the ras family, including Harvey-Ras ( $\mathrm{H}$-ras), Kirsten-Ras (Ki-ras), and Neuroblastoma-ras (N-ras), have been detected in cultured cells of mouse skin tumours following exposure to near-UVR ${ }^{9}$ and are also frequently detected in human neoplastic conditions of sun-exposed body 
areas, such as cutaneous melanomas. ${ }^{10}$ Such mutations may convert these genes into active oncogenes. ${ }^{11}$ Therefore, it is reasonable to assume that mutations in these genes may also be present in ophthalmic pterygia. The purpose of the present study is to evaluate the presence of such mutations and to explore the role they could possibly play in the clinical profile of ophthalmic pterygium.

\section{Materials and methods}

Specimens included in this study were obtained from patients treated at the University Hospital of Heraklion, Crete, Greece. All participants gave written informed consent to a protocol approved by the Institutional Review Board in conformity with the tenets of the Declaration of Helsinki. Pterygia were excised in toto, under local anaesthesia, using the bare sclera technique. ${ }^{1}$ In each case, a blood sample and a conjunctival biopsy from a site relatively protected from solar radiation (corneoscleral limbus, 12 O'clock) were obtained. Immediately after surgery, tissue specimens (either pterygia or conjunctiva) and blood samples were stored at -70 and $4{ }^{\circ} \mathrm{C}$, respectively, until DNA extraction.

In all, 50 pterygia were obtained, 24 (48\%) from males. The average age (mean \pm standard error mean, range) was $65 \pm 1.96$ (30-92) years. In 48 cases (96\%), the location of the pterygium was nasal and in two cases (4\%) temporal to cornea. In 26 cases (52\%), pterygium did not extend beyond $1 \mathrm{~mm}$ on the corneal surface, in 22 cases $(44 \%)$, it was moderately advanced (2-3 $\mathrm{mm})$; and in two cases $(4 \%)$, it was advanced $(>3 \mathrm{~mm}){ }^{2}$ In 13 cases $(26 \%)$ pterygium was recurrent (up to four previous operations). Pterygium was reported to exist on the average for $11.89 \pm 1.37$ years $(0.5-35$ years) prior to the excision. A family history (occurrence of pterygium among first-degree relatives) was reported in 11 patients (22\%). The average altitude of patients' residence was $208.8 \pm 30.60(0-800) \mathrm{m}$.

DNA extraction was performed using a standard protocol with organic detergents. ${ }^{12}$ The yield of DNA from the excised pterygia and conjunctival specimens was on the average $10 \mu \mathrm{g}$. Initial DNA concentration was determined by agarose gel electrophoresis and then titrated to $200 \mu \mathrm{g} / \mathrm{ml}$. Subsequently, a $50 \mu \mathrm{l}$ PCR reaction (35 cycles) was performed. The same PCR system was used in all cases (MJ Research Inc., USA). The premix solution contained $200 \mathrm{ng}$ of genomic DNA, $1 \mu \mathrm{M}$ of each primer, $250 \mu \mathrm{M}$ dNTPs, $5 \mu \mathrm{l}$ of $10 \mathrm{X}$ buffer $(670 \mathrm{mM}$ Tris. $\mathrm{HCl}, \mathrm{pH} 8.5 ; 166 \mathrm{mM}$ ammonium sulphate; $67 \mathrm{mM}$ magnesium chloride; $1.7 \mathrm{mg} / \mathrm{ml} \mathrm{BSA} ; 100 \mu \mathrm{M}$ $\beta$-mercaptoethanol and $1 \%(\mathrm{w} / \mathrm{v})$ Triton $\mathrm{X}-100)$, and $1 \mathrm{U}$ of Taq DNA polymerase (Life Technologies Ltd, UK). Primers used were selected to amplify a sequence containing codons 12 and 13 in N-ras, Ki-ras, and H-ras, as described elsewhere. ${ }^{13,14}$ The primer sequences and the length of PCR products are shown in Table 1.

Reactions were denatured at $94^{\circ} \mathrm{C}$ for 3 min initially. In all, 35 cycles were used in all cases. In each cycle, denaturation was performed at $94^{\circ} \mathrm{C}$ for $60 \mathrm{~s}$ (in all cases), annealing was performed at $58^{\circ} \mathrm{C}$ for $40 \mathrm{~s}$ (Ki-ras and $\mathrm{N}$-ras) and $64^{\circ} \mathrm{C}$ for $40 \mathrm{~s}$ (H-ras), and extension was performed at $72^{\circ} \mathrm{C}$ for $50 \mathrm{~s}$ (in all cases). A final extension was also used in all cases $\left(72^{\circ} \mathrm{C}\right.$ for $\left.7 \mathrm{~min}\right)$.

An RFLP analysis was then performed to detect mutations in codon 12 , as previously described. ${ }^{13-15}$ The PCR products were processed with the Wizard PCR Preps DNA purification Clean kit (Promega, Southampton, UK) to remove unincorporated primers and dNTP. In the case of Ki-ras and N-ras, $10 \mu \mathrm{l}$ of the PCR product was digested overnight with $30 \mathrm{U}$ of $B s t \mathrm{NI}$ endonuclease (New England BioLabs Inc., USA) at $60^{\circ} \mathrm{C}$, in a buffer solution containing $50 \mathrm{mM} \mathrm{NaCl}, 10 \mathrm{mM}$ Tris$\mathrm{HCl}, 10 \mathrm{mM} \mathrm{MgCl} 2,1 \mathrm{mM}$ dithiothreitol, and $100 \mu \mathrm{g} / \mathrm{ml}$ BSA $(\mathrm{pH}=7.9)$. In the case of $\mathrm{H}$-ras, overnight digestion of $10 \mu \mathrm{l}$ of PCR product at $37^{\circ} \mathrm{C}$ in a buffer solution (50 mM NaCl, $10 \mathrm{mM}$ Tris- $\mathrm{HCl}, 10 \mathrm{mM} \mathrm{MgCl}, 1 \mathrm{mM}$ dithiothreitol, $\mathrm{pH}=7.9)$ containing $30 \mathrm{U}$ of $\mathrm{MspI}$ endonuclease (New England BioLabs Inc., USA) was employed. The final volume of the restriction digests was $15 \mu \mathrm{l}$ (including $1 \mu \mathrm{l}$ of buffer solution, $3 \mu \mathrm{l}$ of distilled water, $1 \mu \mathrm{l}$ of enzyme and $10 \mu \mathrm{l}$ of PCR product). Subsequently, $10 \mu \mathrm{l}$ of the incubation solution was electrophoresed in a $10 \%$ polyacrylamide gel, together

Table 1 Primer sequences used and respective PCR product in PCR amplification of Ki-ras, $H$-ras and N-ras sequences

\begin{tabular}{|c|c|c|c|}
\hline Gene & & Primer sequences & Product \\
\hline \multirow[t]{2}{*}{ Ki-ras } & Forward & 5'-ACTGAATATAAACTTGTGGTAGTTGGACCT-3' & \multirow[t]{2}{*}{$157 \mathrm{bp}$} \\
\hline & Reverse & $5^{\prime}$-TCAAAGAATGGTCCTGGACC-3' & \\
\hline \multirow[t]{2}{*}{ H-ras } & Forward & 5'-GAGACCCTGTAGGAGGACCC-3' & \multirow[t]{2}{*}{$312 \mathrm{bp}$} \\
\hline & Reverse & 5'-GGGTGCTGAGACGAGGGACT-3' & \\
\hline \multirow[t]{2}{*}{ N-ras } & Forward & 5'-GGGTGCTGAGACGAGGGACT-3' & \multirow[t]{2}{*}{$83 \mathrm{bp}$} \\
\hline & Reverse & 5'-ATATTCATCTACAAAGTG GTCCTGGA-3' & \\
\hline
\end{tabular}


Table 2 Postdigestion sequences for N-ras, H-ras, and Ki-ras

\begin{tabular}{|c|c|c|c|c|}
\hline \multirow[t]{2}{*}{ Gene } & \multirow[t]{2}{*}{ Initial PCR sequence ( $b p)$} & \multirow[t]{2}{*}{ Enzyme } & \multicolumn{2}{|c|}{ Post-digestion sequences } \\
\hline & & & Wild type & Mutated type (codon 12) \\
\hline N-ras & 83 & Bst NI endonuclease & $19 b p+23 b p+41 b p$ & $23 b p+60 b p$ \\
\hline H-ras & 312 & MspI endonuclease & $21 b p+55 b p+236 b p$ & $21 b p+291 b p$ \\
\hline Ki-ras & 157 & Bst NI endonuclease & $15 b p+113 b p+29 b p$ & $15 b p+142 b p$ \\
\hline
\end{tabular}

with undigested PCR product, and silver stained. Postdigestion sequences ${ }^{15}$ for $\mathrm{N}$-ras, $\mathrm{H}$-ras, and Ki-ras are presented in Table 2.

Further exploration of the mutational status of specimens was performed with sequencing of PCR products. Sequencing enabled the evaluation of codons 12 and 13, located in the same amplified ras region (exon 1). The PCR products were resolved through $2 \%$ agarose gels, excised, and processed with the Wizard PCR Preps DNA purification Clean kit (Promega, Southampton, UK) to remove unincorporated primers and dNTP. The sequencing reaction contained: $4 \mu \mathrm{l}$ Big Dye Terminator ready-reaction mix (PE ABI, Warrington, UK), $2 \mu \mathrm{l}$ of cleaned PCR product, and $1.6 \mathrm{pmol}$ of sequencing primer in a total reaction volume of $10 \mu \mathrm{l}$. Reaction conditions were: $96^{\circ} \mathrm{C}$ for $10 \mathrm{~s}, 50^{\circ} \mathrm{C}$ for $10 \mathrm{~s}$ and $60^{\circ} \mathrm{C}$ for $4 \mathrm{~min}, 25$ cycles. Sequencing products were precipitated with isopropanol to remove unincorporated dye terminators and resuspended in $4 \mu \mathrm{l}$ of loading buffer (formamide:dextran sulphate/ethylenediamine tetraacetic acid, 5:1). Products were run on a 377 ABI PRISM automatic sequencer and analysed with the Sequencing Analysis ${ }^{\mathrm{TM}}$ software (PE ABI, Warrington, UK). Both strands were sequenced for each PCR product.

A statistical analysis of results was performed using SPSS 8.0 (SPSS Inc., Chicago, IL, USA). Statistical significance was set at 0.05 .

\section{Results}

The RFLP analysis revealed heterozygous Ki-ras mutations at codon 12 in five cases $(10 \%)$ of the examined pterygia. No H-ras or $\mathrm{N}$-ras mutations were detected in any of the examined pterygia specimens. Mutations were also not detected in blood or conjunctiva specimens for any of the genes examined. Examples of specimens displaying heterozygous Ki-ras mutations (RFLP analysis) are shown in Figure 1.

Sequencing confirmed Ki-ras mutations at codon 12. Specimens mutated at codon 12 of Ki-ras displayed a transition from GGT (glycine) to GTT (valine) in all cases. The lack of mutations at codon 12 of Ki-ras for conjunctival and blood specimens was also confirmed with sequencing. Furthermore, no Ki-ras mutations at

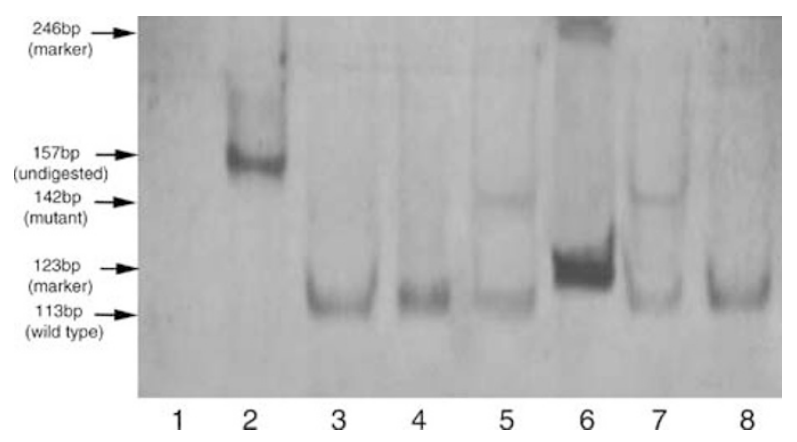

Figure 1 Silver-stained $10 \%$ polyacrylamide gel showing two heterozygous K-ras mutations in specimens of ophthalmic pterygia. Specimens in lanes are as follows: Lane $1=$ blank, lane $2=$ undigested PCR product, Lanes 3, 4, 8=wild-type specimens, lanes 5 and $7=$ mutated specimens, lane $6=123 \mathrm{bp}$ marker.

codon 13 were detected for any of the examined pterygia, conjunctiva, or blood specimens. With respect to $\mathrm{H}-$ ras and $\mathrm{N}$-ras, sequencing revealed a lack of mutations at codons 12 and 13 for all examined specimens, including pterygia, normal conjunctiva, and peripheral blood.

Sequencing profiles for a pterygium specimen mutated at codon 12 of Ki-ras as well as a nonmutated pterygium specimen are presented in Figure 2.

Mutations in Ki-ras were more common in recurrent pterygia (Fisher's exact test, one-tail $P$ value $=0.02$, twotail $P$ value $=0.02$ ). Furthermore, patients displaying Kiras point mutations at codon 12 were of significantly younger age compared with patients not displaying such mutations $(54.50 \pm 8.31$ and $66.31 \pm 1.97$ years, respectively, independent-samples $t$-test value $=1.96$, $P=0.04$ ). The correlation between Ki-ras mutations and gender, altitude of present residence, family history of pterygium, size and location of the lesion, and time interval that pterygium was reported to exist was statistically insignificant.

\section{Discussion}

With the present study, we aimed at screening specimens of ophthalmic pterygium for mutations at codons 12 (RFLP and sequencing analysis) and 13 (sequencing analysis) of the members of the ras gene family. Ras genes 
a
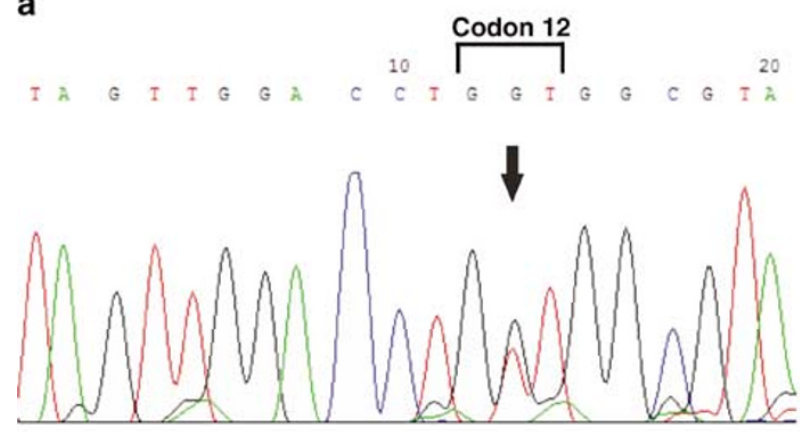

b
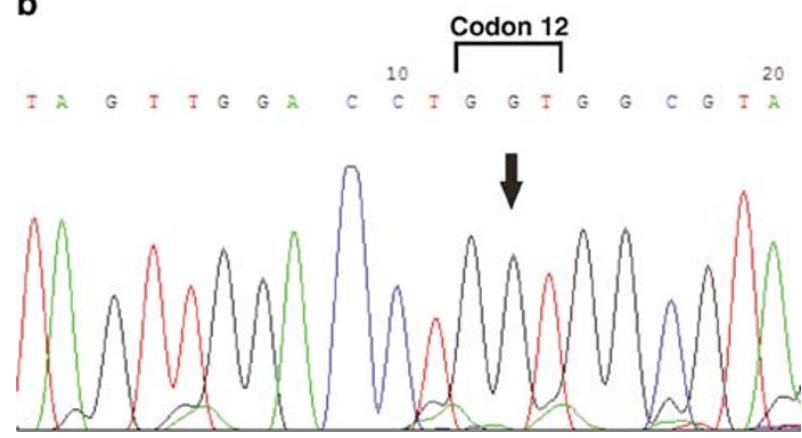

Figure 2 Sequencing profiles of mutated (a) and nonmutated (b) pterygia specimens. A heterozygous point mutation at the second base of codon 12 ( $G$ to $T$ ) is detected, signifying a change from glycine to valine at that codon for the p21 protein.

are implicated in several different malignancies and have been shown to be mutated in $10-15 \%$ of human solid tumors. ${ }^{16,17}$ Point mutations at critical domains, such as codons 12,13 , and $61^{18}$ is a common mechanism of ras gene activation. ${ }^{17}$

Mutations in members of the ras family genes, especially N-ras, are often found in cutaneous conditions, such as cutaneous melanoma, associated with exposure to UVR. ${ }^{10,11}$ However, it has been reported that N-ras mutations are considerably more rare in mucosal lesions than in cutaneous lesions. ${ }^{10}$ In a previous study assessing the role of $\mathrm{N}$-ras mutations in conjunctival melanomas, no such mutations were detected. ${ }^{11}$ Our findings are in agreement with these reports and indicate that N-ras and $\mathrm{H}$-ras are possibly not mutated at codons 12 and 13 in the case of ophthalmic pterygium.

However, the detection of Ki-ras mutations at codon 12 and especially the significant correlation between Ki-ras mutations and the postoperative recurrence as well as the young age imply a possible role of such mutations in the pathogenesis and biological profile of ophthalmic pterygium. The ras family gene product (protein p21) belongs to the small GTP-binding proteins (G proteins) and regulates gene expression. ${ }^{19}$ Small GTP-binding protein GDP dissociation stimulator (Smg GDS) regulates GDP/GTP exchange reaction of ras and the Rho and
Rap1 family members and inhibits their binding to membranes. ${ }^{19}$ In fibroblasts, Smg GDS shows mitogenic and transforming activities in cooperation with Ki-ras, possibly through antiapoptotic cell survival signalling. ${ }^{19}$ It was recently reported that pterygia display different paterns of apoptosis and expression of $b c l-2$ and bax compared to normal adjacent conjunctiva and it was suggested that deregulation of apoptosis may be an underlying mechanism leading to pterygium development. ${ }^{20}$ The possible involvement of Ki-ras in the pathogenesis and biological behaviour of ophthalmic pterygium complies with these findings and further supports the concept that pterygium may be a neoplastic condition.

The transition from GGT (glycine) to GTT (valine) at codon 12 of Ki-ras has often been described in the past in various tumors, including pancreatic, ${ }^{21}$ lung $^{22}$ and colon $^{23}$ cancers. There are conflicting reports on its clinical significance. ${ }^{24,25}$ Some studies report that it is an innocuous mutation characteristic of indolent tumours, ${ }^{24}$ whereas others report that it is characteristic of more aggressive forms of neoplasia, including metastatic tumours. ${ }^{25}$ The same transition has been described in preneoplastic lesions, such as aberrant crypt foci (ACF) in the colon, ${ }^{26}$ or even phenotypically normal mucosa located near neoplastic lesions, as in the case of nonneoplastic mucosa from bronchial carina in patients with lung adenocarcinomas. ${ }^{27}$ In the present study, mutations were not observed in control tissues, including peripheral blood and phenotypically normal conjunctival specimens, harvested from the same patients, implying that the mutations detected may be specific for pterygium.

The mechanism of genetic damage to Ki-ras is unclear. Genetic lesions previously detected in pterygia, such as $\mathrm{LOH}$ and mutations to $\mathrm{P} 53^{4}$ were, in some cases, directly correlated to the level of exposure to UVR or were located in regions with known susceptibility to UVR, such as $9 q$ or $17 p . .^{5}$ In the present study, Ki-ras mutations were not detected in conjunctival specimens excised from areas located under the upper eyelid and thus protected from the solar light. However, mutations to N-ras, which have been reported to be highly susceptible to UVR, ${ }^{10,11}$ were not detected in any case. Furthermore, the altitude of residence, which is correlated with the exposure to $\mathrm{UVR}^{5}$ was not significantly higher in patients displaying Ki-ras mutations. Therefore, although absent in areas with less exposure to solar light, mutations detected could be independent of the action of UVR.

Postoperative recurrence is an important problem in the management of pterygia and repeated operations often lead to extensive scarring and symblephara formation, thus adding to the discomfort of patients and further reducing vision. ${ }^{1}$ Furthermore, pterygium is a 
very common condition in populations with a high level of exposure to solar light. ${ }^{2}$ Understanding the exact nature of this condition, which could lead to new, less aggressive and more effective methods of treatment, is therefore important. The role of the ras gene family in the pathogenesis of pterygium could be further examined by evaluating mutations to other codons, such as 61 , which are also critical for the function of p21, as well as by assessing the expression of the ras genes in both pterygia and normal conjunctiva. Apart from helping in understanding the pathogenesis of pterygium, research towards this goal may also have strong therapeutic implications as it could enable alternative methods of treatment, such as gene therapy by introducing normal genetic material in affected cells.

\section{References}

1 Waller SG, Adamis AP. Pterygium. In: Duane's Ophthalmology, Vol 6, Chapter 35. Tasman W, Jaeger E (eds). J.B.Lippincott (co): Philadelphia, 1994, pp 1-10.

2 Coroneo MT. Pterygium as an indicator of ultraviolet insulation: a hypothesis. Br J Ophthalmol 1993; 77: 734-739.

3 Taylor HR, West SK, Rosenthal FS, Munoz B, Newland HS, Emmett EA. Corneal changes associated with chronic UV irradiation. Arch Ophthalmol 1989; 107(10): 1481-1484.

4 Detorakis ET, Drakonaki EE, Spandidos DA. Molecular genetic alterations and viral presence in ophthalmic pterygium (Review). Int J Mol Med 2000; 6: 35-41.

5 Detorakis ET, Sourvinos G, Tsamparlakis J, Spandidos DA. Evaluation of loss of heterozygosity and microsatellite instability in human pterygium: clinical correlations. $\mathrm{Br} \mathrm{J}$ Ophthalmol 1998; 82: 1324-1328.

6 Detorakis ET, Sourvinos G, Spandidos DA. Detection of herpes simplex virus and human papilloma virus in ophthalmic pterygium. Cornea 2001; 20: 164-167.

7 Dushku N, Reid TW. $P 53$ expression in altered limbal basal cells of pingueculae, pterygia, and limbal tumors. Curr Eye Res 1997; 16: 1179-1192.

8 Dushku N, Reid TW. Immunohistochemical evidence that human pterygia originate from an invasion of vimentinexpressing altered epithelial basal cells. Curr Eye Res 1994; 13: $473-481$.

9 Nishigori C, Wang S, Miyakoshi J, Sato M, Tsukada T, Yagi T et al. Mutations in ras genes in cells cultured from mouse skin tumors induced by ultraviolet irradiation. Proc Natl Acad Sci USA 1994; 19: 7189-7193.

10 Jiveskog S, Ragnarsson-Olding B, Platz A, Ringborg U. $\mathrm{N}$-ras mutations are common in melanomas from sun-exposed skin of humans but rare in mucosal membranes or unexposed skin. J Invest Dermatol 1998; 111: 757-761.

11 El-Shabrawi Y, Radner H, Muellner K, Langmann G, Hoefler $\mathrm{G}$. The role of UV-radiation in the development of conjunctival malignant melanoma. Acta Ophthalmol Scand 1999; 77: 31-32.
12 Mc Pherson MJ, Quirke P, Taylor GR. PCR. A Practical Approach. Oxford University Press: Oxford, 1991.

13 Glarakis IS, Savva S, Spandidos DA. Activation of the ras genes in malignant and premalignant colorectal tumors. Oncol Rep 1998; 5: 1451-1454.

14 Jiang W, Kahn SM, Guillem JG, Lu SH, Weinstein IB. Rapid detection of ras oncogenes in human tumors: applications to colon, esophageal and gastric cancers. Oncogene 1989; 4: 923-928.

15 Koffa M, Malamou-Mitsi V, Agnantis NJ, Spandidos DA. Mutational activation of K-ras oncogene in human breast tumours. Int J Oncol 1994; 4: 573-576.

16 Anderson JA, Irish JC, Ngan BY. Prevalence of RAS oncogene mutation in head and neck cancer. J Otolaryngol 1992; 21: 321-326.

17 Field JK, Spandidos DA. The role of ras and myc oncogenes in human solid tumors and their relevance in diagnosis and prognosis. Anticancer Res 1990; 10: 1-22.

18 Barbacid M. Ras genes. Ann Rev Biochem 1987; 56: 779-827.

19 Takakura A, Miyoshi J, Ishizaki H, Tanaka M, Togawa A, Nishizawa $\mathrm{Y}$ et al. Involvement of a small GTP-binding protein (G protein) regulator, small G protein GDP dissociation stimulator, in antiapoptotic cell survival signaling. Mol Biol Cell 2000; 11: 1875-1886.

20 Tan DT, Tang WY, Liu YP, Goh HS, Smith DR. Apoptosis and apoptosis related gene expression in normal conjunctiva and pterygium. Br J Ophthalmol 2000; 84: 212-216.

21 Aoki Y, Hosaka S, Tachibana N, Karasawa Y, Kawa S, Kiyosawa K. Reassessment of K-ras mutations at codon 12 by direct PCR and sequencing from tissue microdissection in human pancreatic adenocarcinomas. Pancreas 2000; 21: 152-157.

22 Hilbe W, Dlaska M, Duba HC, Dirnhofer S, Eisterer W, Oberwasserlechner F et al. Automated real-time PCR to determine K-ras codon 12 mutations in non-small cell lung cancer: comparison with immunohistochemistry and clinico-pathological features. Int J Oncol 2003; 23: 1121-1126.

23 Kusaka T, Fukui H, Sano Y, Ueda Y, Chiba T, Fujimori T. Of $\mathrm{K}$-ras codon 12 mutations and p53 overexpression in colorectal nodule-aggregating tumors. J Gastroenterol Hepatol 2000; 15: 1151-1157.

24 Finkelstein SD, Sayegh R, Christensen S, Swalsky PA. Genotypic classification of colorectal adenocarcinoma. Biologic behavior correlates with K-ras-2 mutation type. Cancer 1993; 71: 3827-3838.

25 Al-Mulla F, Going JJ, Sowden ETHH, Winter A, Pickford IR, Birnie GD. Heterogeneity of mutant versus wild-type Ki-ras in primary and metastatic colorectal carcinomas, and association of codon-12 valine with early mortality. J Pathol 1998; 185: 130-138.

26 Yamashita N, Minamoto T, Ochiai A, Onda M, Esumi H. Frequent and characteristic K-ras activation in aberrant crypt foci of colon. Is there preference among K-ras mutants for malignant progression? Cancer 1995; 75 (6 Suppl): 1527-1533.

27 Urban T, Ricci S, Danel C, Antoine M, Kambouchner M, Godard V et al. Detection of codon $12 \mathrm{~K}$-ras mutations in non-neoplastic mucosa from bronchial carina in patients with lung adenocarcinomas. Br J Cancer 2000; 82: 412-417. 